\title{
Using the 'Best-fit' Approach to Investigate the Effects of Politico-economic and Social Barriers on SMEs' Internationalisation in an Emerging Country Context: Implications and future directions
}

\author{
John Mendy, Mahfuzur Rahman \& P. Matthijs Bal \\ Correspondence
}

John Mendy, Senior Lecturer/Programme Lead

University of Lincoln

Lincoln International Business School

Lincoln, LN6 7TS

UK

Email: jmendy@lincoln.ac.uk

\begin{abstract}
The way this study has used the 'best fit' approach has facilitated the study of how three hypothesised constructs of political, economic and social barriers can deepen our knowledge of their impacts on SMEs' internationalisation within a small developing country context. Based on a quantitative analysis of the three hypothesised barriers, we used the 'best fit' approach to measure the extent to which the SMEs' internal variables like people, products, services and practices might best fit some of the people and non-people factors external to the businesses. The application of the 'best-fit' approach onto the three hypotheses (politics (H1), social (H2), economics (H3)), helped us in explaining the major social and politico-economic barriers faced by a developing economy's (Bangladeshi) SMEs' internationalisation despite previous literatures' emphasis on the impacts of globalisation, market drivers or their oversight. Based on the findings we point to future research trajectory. This study used primary survey data from 212 Bangladeshi SMEs and successfully validated an HR Model by using Smart PLS3 software. The results from the hypotheses were used to produce the HR Model to help
\end{abstract}


SMEs identify the significance of people and economic factors and propose these aspects for inclusion in the 'best-fit' approach, SME and globalisation research.

Keywords: Best-fit approach, SMEs, HR Model, developing country, internationalisation 


\section{INTRODUCTION}

SMEs have contributed to boosting the growth of developing countries' economies. Previous research has focused on the factors constraining SMEs' growth in foreign markets (Okpara \& Kabongo, 2011) as well as their positive economic contributions (SteinerowskaStreb \& Steiner, 2014; Buckley \& Ghauri, 2016), thereby signalling the importance of internationalisation. Internationalisation of business activities involves not only trade across borders but also the processes by which firms seek to increase their business's involvement externally (Liesch, Welch \& Buckley, 2014; Newman, Borgia \& Deng, 2013). Calls for businesses to adapt operations internationally (Fletcher \& Prashantham, 2011) have focused on human capital (Ruzzier et al., 2007), the use of people management practices (Paul \& Anantharaman, 2003) and its benefits (Kamakura, Ramon-Jeronimo \& Gravel, 2012; Vissak \& Zhang, 2012). However, these studies are criticised for failing to take into account SMEs' size, capacity and the way goods and services undergo inward mobility as part of a process of internationalisation (Balboni, Bortoluzzi \& Grandinetti, 2013). Recently, other researchers have viewed internationalisation as a set of economically related activities that show how a firm expands its operations across a nation's geographic boundaries (Ruzzier et al., 2007). In this paper, we view internationalisation as a set of economic and people-related activities via which firms seek to move their inward goods and services across borders.

By focusing on the theoretical foundations of internationalisation including those by Paul, Parthasarathy and Gupta (2017), we aim to assess the extent to which the theoretical aspects apply in a developing country context and how an HR model were contributed to deepen our understanding of the political, economic and social issues involved. However, other scholars have looked into the theoretical aspects and the questions raised by globalisation (Liñán, Paul \& Fayolle, 2019). Some of the theoretical recommendations highlight the benefits to 'organic' networks of social and business relationships (Fletcher \& Prashantham, 2011) in 
facilitating SMEs' internationalisation activities or the contributions made by young managers. (Paul \& Shrivatava, 2016). However, we still do not know the extent to which the factors that determine the movement of goods and services (Williams et al., 2014) are measured and what their implications on the economic benefits and barriers are (Buckley \& Ghauri, 2016). Often, the fast 'pace of globalisation' (Ghauri et al., 2016) and the growing influence of technology (Stone \& Deadrick, 2015) are considered as separate from other 'market drivers' (Jaworksi, Kohli \& Sahay, 2011; Zoogah \& Mburu, 2015) thereby questioning SMEs' internationalisation legitimacy (Saridakis et al., 2017).

When barriers to SMEs' internationalisation are investigated a number of aspects including employee disengagement, entrepreneurial non-commitment, under-performance and trust are highlighted (von Bonsdorff et al., 2015). However, we do not know the extent to which the HR strategies (Ulrich \& Dulebohn, 2015) impact on the macro political and situational factors from a developing country angle. Hence, to date there is no model that looks into capturing the environmental and behavioural factors because of internationalisation (Lindner, Muellner \& Puck, 2016). As part of the study's objective, we have developed an HR model capturing the complexities involved in the process.

To do so, we combine three main factors of politics and economics and the social to study and deepen our understanding of the barriers to SMEs' internationalisation (Rahman, Uddin \& Lodorfos, 2017) by using the 'best fit' approach to focus on identifying internal and external factors that contribute to the barriers to internationalisation (Stone \& Deadrick, 2015). We hypothesise the three main barriers as constructs for their survival, given their limited exploration. The most investigated construct is economic. The internationalisation theories focus on the measurement of relationship between market performance and financial and foreign exchange factors. However, given the significant variation in reporting systems across economies and highlighting what relationships might prove more beneficial in capturing a more 
complex internationalisation picture, we include and examine additional factors such as politics, legal, procedural and developmental factors in our hypothesis and model development because these have not been investigated previously.

Based on the literature we examine characteristics of the 'best fit' and 'best practices' to determine our justification of applying the characteristics onto the internal and external variables (i.e. barriers) in developing a new HR model as this paper's contribution to SMEs' internationalisation. This approach was adopted because we still do not know whether applying a set of people-related practices and procedures in a specific developing country (i.e. by using the 'best fit') will be sufficient guarantee for SMEs to do well internationally. We want to find an alternative or an amended version of Becker and Huselid's (2006) 'best-fit' approach that fits within a developing country by measuring the three variables (i.e. the three barriers to study SMEs' internationalisation) given their under-representation in the SME and internationalisation literature on people and non-people-related factors. Therefore, in order to develop a model, our research question is 'what are the politico-economic and social barriers faced by SMEs as they try to do business in foreign or international markets?'

\section{LITERATURE REVIEW}

\section{Best-fit approach}

Two HRM models popularly referred to as the 'best fit' and 'best practice' (Paauwe \& Boselie, 2005) are used to describe interactions (e.g. between internal organisational practices and external activities). Three major hypotheses on SMEs' internationalisation barriers are used to see whether an alternative model can be developed on how SMEs in a developing country manage people, goods/products and services and thereby contribute to the theoretical debates and discussions such as those raised by Liñán, Paul and Fayolle (2019). The best-fit approach points to how to manage people both within as well as outside a company. The model assumes 
that there is an internal fit between people, products, services and practices and the external environment. However, it does not take into account the obstruction of 'fit' by barriers to SMEs' internationalisation. The 'best-fit' proponents like Boxall and Purcell (2003) argue that a firm's people-related practices fosters employee commitment and engagement through an internal application of pay and reward, disciplinary procedures and team working. Whether such an application helps us unravel the internationalisation issues and complexities or even what managers may contribute (Paul \& Shrivatava, 2016) remains to be discovered. Therefore, it appears logical to use O'Farrell and colleagues' (1996) 'best fit' model because it caters for the internationalisation issues (e.g. mobility of people, goods and services in foreign markets). Consequently, an interchangeable usage of the two terms in the tradition of Paauwe and Boselie (2005) or Becker and Huselid's (2006) limited usage to focus on firm performance or Boxall and Purcell's (2003) internal usage were not adopted.

The theoretical foundations of internationalisation are polarised in terms of the economic content variables including entrepreneurial and employee commitment (von Bonsdorff, Janhonen, Zhou \& Vanhalad, 2015), cross-border teams (Edmondson \& Harvey, 2017) and leadership and trust (Top, Akdere \& Turcan, 2015). An HR model that integrates the complexities has been missing within the informal (Williams \& Horodonic, 2016) and formal entrepreneurial business (Zhou et al., 2017) and even the theoretical postulations (Paul, Parthasarathy \& Gupta, 2017). It is only recently that attempts are made to remedy such missing aspects (Mendy \& Rahman, 2018). However, we still do not know what their impacts on SMEs' service and product mobilisation might be (Balboni, Bortoluzzi \& Grandinetti, 2013; Alon \& Rottig, 2013).

We conceptualise the internationalisation barriers on politics, economics and the social using some existing theories. Political barriers are considered as those company procedures and mechanisms which make the practical use of HR practices in international operations fraught 
(Kaufman, 2015). This is compounded when legal challenges foster a culture of corruption (Chen, Liu \& Su, 2013) thereby making access to legal support (Benito-Hernández, et al., 2015) problematic (Gunaratne, 2009).

The social barriers include language, social norms and practices and staff skills' training. However, developing countries lack training and adequate skilled human capital (Roza, Bosch \& Volberda, 2011) rendering their export barriers problematic (Okpara \& Kabongo 2010). The economic barriers consist of the exchange rate and inflation related costs of firms (Ghosh, Ostry \& Chamon, 2016) adding to their economic difficulties (Hong \& Lu, 2016). Such combinations make SMEs' ability to adjust to and contribute economically more challenging (Cowling, et al., 2015) for financial growth (Domeher, Musa \& Hassan, 2017). However, some SMEs defy the odds internationally (Cavusgil \& Knight, 2015).

However, we do not know whether using 'best practices' in providing employment security, equality and team-work (Boxall \& Purcell, 2003) or 'best fit' can address the political, social and economic barriers as identified, aspects that Liñán, Paul and Fayolle (2019) could have comprehensively looked into. We also do not know whether there might be an alternative model beyond Jaworski et al.'s (2011) 'inward'/'outward' model or Paul and Anantharaman's (2003) people management's impact on performance or Paul and Shrivatava's (2016) managermodel contribution as theorised. By considering theoretical frames that support the 'best fit' model and recent postulations by Mendy and Rahman (2018) we ascertain what implications there might be for SMEs' internationalisation and people management by testing the three hypotheses, two of which have been neglected in a small developing country.

\subsection{Conceptual Model Development}

Based on the analysis above we initially propose the following research model (Figure 1) to highlight the three hypothesised barriers of politics (H1), social (H2) and economics (H3) for SME and Human Resource Management research and practice. 
FIGURE 1. Hypothesis on the internationalisation barriers for SMEs in a small developing country

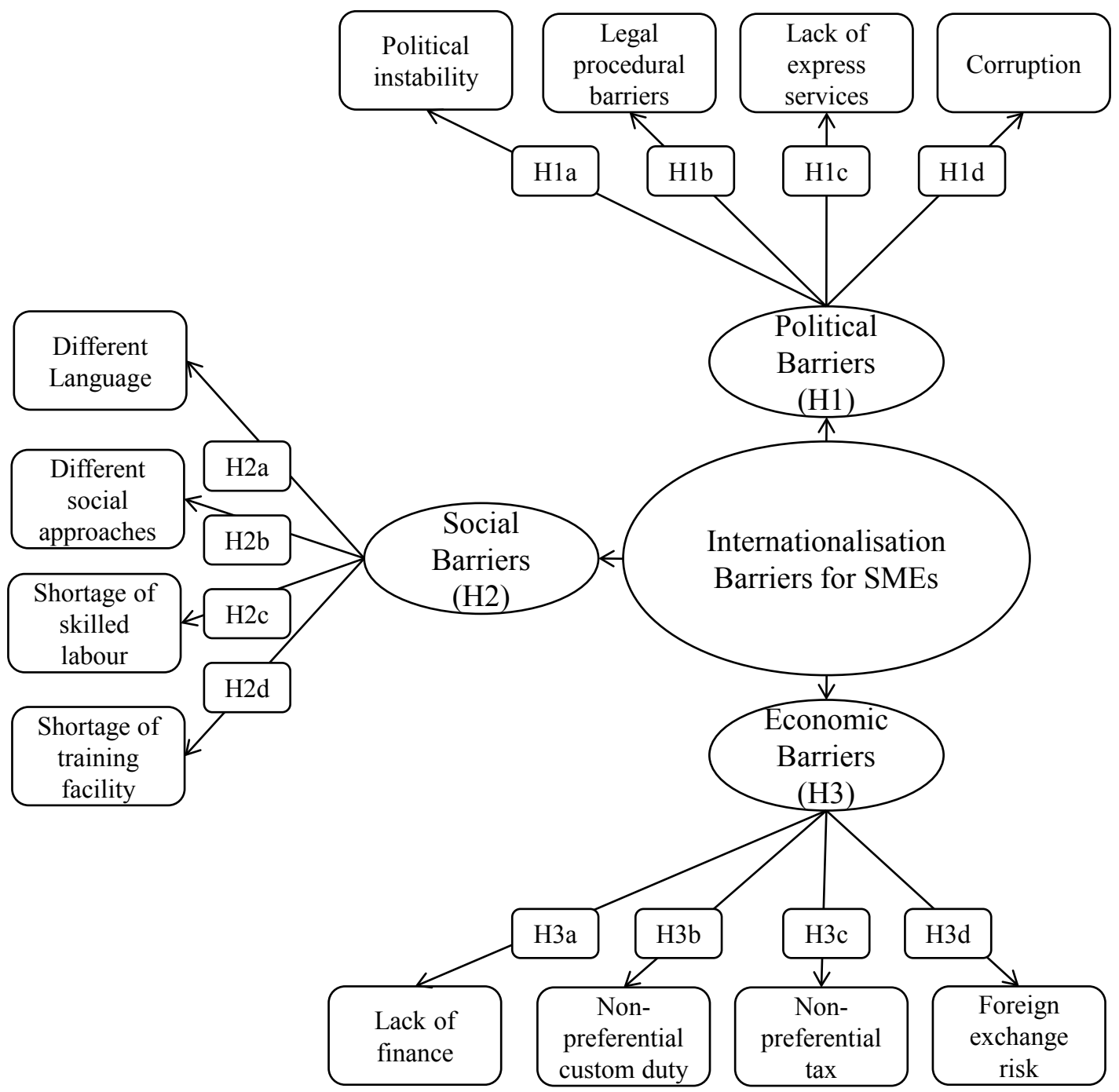

In Figure 1, there are three main hypotheses formed based on the conditional barriers derived from literatures on the internationalisation of SMEs. Each of the three hypotheses relate to social, political and economic conditions/dimensions as SMEs from a developing country seek to enter developed countries' foreign markets.

\subsubsection{Political and legal barriers}

Three SME internationalisation barriers are identified as political (H1), social (H2) and economic (H3). The literature highlights how the use of power can render a political barrier 
and render a firm's dependence on HR practices, policies and procedures (Johns, 1993) open to 'greasing the wheels' for such internationalisation (Dutta \& Sobel, 2016) something missed by Paul, Parthasarathy and Gupta (2017). Negative consequences threaten such SME expansion (Mendoza, Lim \& Lopez, 2015).

Legal support may be sought by individuals and companies for a multitude of reasons, including saving a firm's face (Harrison, Boivie \& Sharp, 2018) when the business is under threat of extinction or loss of reputation (Gunaratne, 2009). However, legal support is sometimes unavailable (Benito-Hernández, et al., 2015) even in developed countries. Based on the above analysis, we hypothesise that:

H1a: Political barriers and SMEs' internationalisation best fit political instability,

H1b: Political barriers and SMEs' internationalisation best fit legal procedural barrier,

H1c: Political barriers and SMEs' internationalisation best fit lack of express service,

H1d: Political barriers and SMEs' internationalisation best fit corruption,

2.2.2 Social barriers and skills' acquisition.

The 'best fit' model conflates HRM practices into a set of organisational business activities and practices (Marchington \& Grugulis, 2000), whose acceptance becomes legitimised in a social medium such as language or a set of values and behaviours (Meyer and Rowan, 1977). Despite this, practices vary from company to company and therefore are not "rule-like" (Okpara \& Kabongo 2010).

Skill denotes the ability to perform a task, often successfully (Naumann et al., 2008). Although contextual conditions may account for differences, firms in developing countries struggle for skills' capacity (Beine, Docquire \& Rapoport, 2008) even though such shortage of skilled labour and its impact have received muted attention. Based on the above analysis, we posit the following hypotheses: 
H2a: Social barriers and SMEs' internationalisation best fit language acquisition lag,

H2b: Social barriers and SMEs' internationalisation best fit a lack of social aspects,

H2c: Social barriers and SMEs' internationalisation best fit skilled labour deficit,

H2d: Social barriers and SMEs' internationalisation best fit lack of training.

\subsubsection{Economic and financial barriers}

Economic activity is an important criterion for economic growth (Boso, et al., 2016). These and interest, exchange and inflation rates continue to impact on businesses' cost of capital, business ownership by international firms (Ghosh, Ostry \& Chamon, 2016). Although economic and financial barriers affect SMEs and MNEs, SMEs are more vulnerable to economic fluctuations (Cowling, et al., 2015) and resource constraints (Hong and Lu, 2016) and growth obstacles (Domeher et al., 2017; Brouthers et al., 2015). The ability to sometimes become successful internationally (Cavusgil \& Knight, 2015) calls for some other incentives (Agwu \& Emeti, 2014). To date, there is no study to determine the influence of economic and financial barriers on the internationalisation of Bangladeshi SMEs. The above analysis has led us to propose the following hypotheses:

H3a: Economic barriers and SMEs' internationalisation best fit lack of finance, H3b: Economic barriers and SMEs' internationalisation best fit non-preferential customs duty, H3c: Economic barriers and SMEs' internationalisation best fit non-preferential tax, H3d: Economic barriers and SMEs' internationalisation best fit foreign exchange risk.

\subsection{RESEARCH METHODOLOGY}

This study has proposed an empirically tested HR model based on previous studies' neglect of core elements in the political, economic and social aspects of SMEs' internationalisation 
(Chetty \& Holm, 2000) and the need to see what benefits there might be for SMEs (Fletcher \& Prashantham, 2011). The measurement comprises twelve items (see Figure 1). Four of the items signify the political dimension (political instability, legal procedural barriers, lack of express service and corruption), four items signify the economic dimension (lack of finance, non-preferential custom duty, non-preferential tax and foreign exchange risk) and four items signify the social dimension (different language, different social approach, shortage of skilled labour and shortage of training facility). The participants were requested to complete the survey based on their internationalisation experience and were assured of confidentiality in line with ethical compliance. We used 5-point Likert scale with 1 representing strongly disagree and 5 strongly agree.

To validate the model, an empirical survey was carried out to measure the relationships between the variables (Malhotra, 2008). Common method variance (CMV) is challenging in survey based empirical investigation considering the validity of the findings particularly for the studies with several constructs. This issue is typically more significant for research findings in social and behavioural science (Podasakoff et al., 2003). CMV can also influence the structural relationship as mentioned by Kline, Sulsky and Rever-Moriyama (2000). To address this issue, Harman 1 factor test was applied on the first order latent variables as suggested by Podsakoff and Organ (1986). As the test found no significant biases in the data set, CMV was not considered a major concern for this study. In addition to the CMV, there inherently exists a non-response bias in mail surveys (Wickramasekera \& Oczkowski, 2006). Several methods were applied to overcome this response bias, such as, minimising the number of non-responses through pre notification and reminder; using cluster sampling technique and t-tests on the average of early and late respondents (Armstrong \& Overton, 1977).

\subsection{The Bangladeshi Context}


SMEs' worldwide contribution in sustaining economic development (Madrid-Guijarro, GarcíaPérez-de-Lema, \& Van Auken, 2013) especially after the financial crisis (Li, Segarra Roca, \& Papaoikonomou, 2011) has been increasing whilst the overall contribution of MNEs has been decreasing and sometimes failing (Mwaura \& Nyaboga, 2009). Despite their growing importance a significant number of SMEs fail to grow or survive in the longer time (Masurel \& Van Montfort, 2006) especially when they compete internationally (Pangarkar, 2008) thereby prompting the interest to analyse the key barriers very carefully in this paper. This issue is more significant in emerging economies due to their higher dependency on SMEs' job creation and economic growth potentials compared to those in developed countries. Therefore, the findings from developed countries' SMEs will not be as beneficial in fulfilling this study's objective compared to those in a developing country (Park \& Ghauri, 2011) although we recognise efforts of other scholars' efforts in conducting cross-country comparative studies (Paul \& Shrivatava, 2016).

To contribute to this research limitation, this study had made an effort to explore three major types of barriers of internationalisation of SMEs in the context of Bangladesh whose SMEs contribute significantly to the country's major economic activities. Based on the empirical data, this study developed an HR model on the barriers of internationalisation to add to the theoretical developments in the area as suggested by Paul, Parthasarathy and Gupta (2017). To validate the model, this study used a questionnaire survey, cluster sampling as a sampling technique and partial least square based structural equation modelling (PLS-SEM) as a data analysis technique. The findings of the study show that the barriers of internationalisation are a second order hierarchical model containing three dimensions (political, economic and social) that have a significant theoretical and practical impact in reframing the association with consequential latent variables of internationalisation of SMEs in a developing country (Bangladesh) context. Methodologically, this study validates that component based SEM and 
identifies what the key barriers of internationalisation of SMEs in a Bangladeshi context are. Overall, the study makes a significant contribution in understanding the precautions, support and consequences of SMEs' internationalisation and their longer-term sustainability through the international growth of SMEs from a developing country perspective.

Based on the participants' viewpoints during the piloting stage, this study collected data from international SMEs only. This may pose as a limitation as it raises the issue of potential sample selection bias. However, it could be better to have data from firms thinking of international expansion because this was our principal research objective rather than focusing on data from firms not anticipating to do so. The researchers recognised the potential confusion of combining internationalisation and non-internationalisation firms thereby going against the variance-based analysis used here. The latter is suitable for smaller sample size as ours in order to facilitate complex relationships analysis. This allows the analysis of two or three or more variables as factors depend on each other while allowing the measurement of some constructs by some other indicators (e.g. the 8 individual items/factors). The latter aspect is common in SME research (Dar \& Mishra, 2019; Booltink \& Saka-Helmhout, 2018), whereas the former is not.

\subsection{Questionnaire Survey}

Following the above justification, we collected empirical data from Bangladesh, namely Dhaka, Chittagong, Khulna and Rajshahi in 2011. In each division, 250 questionnaires were distributed using cluster sampling. An equal representation of international SMEs was sought across different regions in Bangladesh. Random sampling technique facilitated the systematic application of the selection procedure of SMEs although the pace at which they internationalised their activities (Jaworski et al., 2011) was different from Ghauri et al.'s (2016) proposition or Paul and Anantharaman's (2003) notion of the impact of people management. A $22 \%$ survey response rate was received from the 1,000 questionnaires posted to respondents. 
219 responses were returned, out of which seven were deemed unsuitable due to excessive missing data. The 212 questionnaire responses were analysed. The demographic profile of this study consist of $68 \%$ male and $32 \%$ female; $51 \%$ manufacturing and the remaining $49 \%$ nonmanufacturing.

All of the items of the questionnaire were measured in five-point Likert-scale. Before the final data collection, a pre-test was carried out among 20 samples and five academics were drafted to ensure the appropriateness of the wording, contents, scales, sequence and format. Very minor amendments were made on the basis of the pre-test and the outcomes. The latter highlighted the people and non-people barriers to enter in foreign markets for Bangladeshi SMEs as an HR model capturing overall latent variables (Jarvis et al., 2003), in our case the social and politico-economic components.

FIGURE 2. Internationalisation Barriers for SMEs as an HR Model

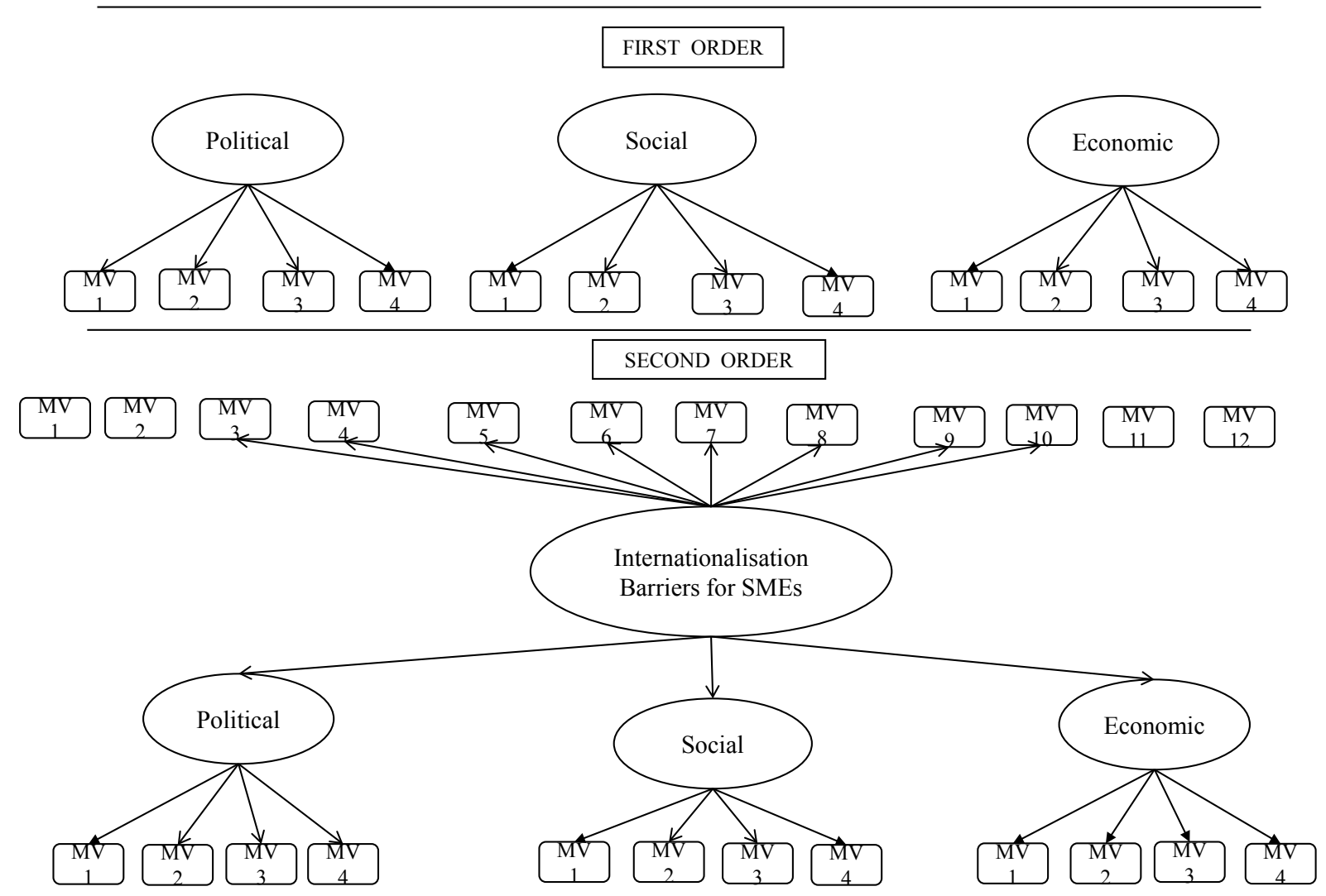


We tested the model by using SmartPLS 3 software (Ringle, Wendy \& Becker, 2015). This least square estimation procedure "maximises the variance of the dependent variables explained by the independent variables" (Jones et al. 2019, p. 38). The model was specified as a reflective-type with the application of repeated indicators. The key analysis is reported in two steps- assessment of higher order model (see next section) followed by the examination of structural model (see next section).

TABLE 2: Estimation of the barriers as a reflective hierarchical model

\begin{tabular}{ll}
\hline First Order & Second Order \\
\hline$y_{\mathrm{i}}=\Delta_{\mathrm{y}} \cdot \eta_{\mathrm{j}+} \varepsilon_{\mathrm{i}}$ & $\eta_{\mathrm{j}}=\Gamma \cdot \xi_{\mathrm{k}}+\zeta_{\mathrm{j}}$ \\
$\mathrm{y}_{\mathrm{i}}=$ manifest variables & $\eta_{\mathrm{j}}=$ first order factors (e.g. political) \\
$\Delta_{\mathrm{y}}=$ loadings of first order latent variables & $\Gamma=$ loadings of second order latent variables \\
$\eta_{\mathrm{j}}=$ first order latent variables (political, & $\xi_{\mathrm{k}}=$ second order latent variables \\
economic and social) & (procedural barrier) \\
$\varepsilon_{\mathrm{i}}=$ measurement error of manifest variables & $\zeta_{\mathrm{j}}=$ measurement error of first order factors \\
& \\
\hline
\end{tabular}

The study's estimation equations for the first and second order hierarchical reflective models are shown in Table 2 above. The equation for the first-order representation specifies first-order MVs (yi), latent variable ( $(\mathrm{j})$, loadings $(\Delta y)$ and an error term ( $(\varepsilon i)$. The equation of the secondorder representation specifies the first-order factors ( $\eta \mathrm{j}$ ) in terms of the second-order latent variables $(\xi \mathrm{k})$ and error $\left(\zeta_{\mathrm{j}}\right)$ for the first-order factor and second-order latent variable loadings $(\Gamma)$.

Three research stages that were undertaken included evaluation/analysis of measurements and linkages as predictors of internationalisation barriers, assessment of representation and testing the representational relationships in order to facilitate data presentation, research validity as well as reliability before any conclusions on the hypotheses were made. Therefore, this study used a structural model as an alternative to the first generation regression techniques. Using the second-generation analytical technique helped in identifying how two apparently different variables (e.g. human and economic) can be dependent but assist in appropriately measuring 
actual internationalisation barriers. The second-generation technique has made modelling multiple aspects of relationship constructs between people and non-people aspects at the same time using SEM possible.

\section{RESULTS}

\section{Analysis of model}

This study used PLS 3 (Wetzels et al., 2009) to measure the internationalisation barriers. Path modelling technique facilitated estimation of variables (Akter et al., 2010). Factors such as social, political and economic barriers of Bangladeshi SME internationalisation are measured using the MV indicators, an area that eluded Liñán, Paul and Fayolle (2019). We then carried out a confirmatory factor analysis to test the model and analyse the extent of its validity and reliability. The tests found no significant differences; therefore, non-response bias is not an issue for this investigation.

Table 3 shows that the individual item loading is higher than 0.70 and which is also significant at 0.01 . Further, reliability of the scale is assessed through the composite reliability (CR), Cronbach's $\alpha(\mathrm{CA})$ and average variance extracted (AVE) as recommended by Akter et al. (2010). The result (Table 1) finds that the $\mathrm{CR}$ and $\mathrm{CA}$ values (H1, H2 \& H3) are above the 0.70 entry point recommended by Brereton and Lloyd (2014) (Hulland, 1999 for earlier version. The AVE for people and politico-economic barriers are also noted to be higher than 0.50 . The results show variance from the items thereby ensuring convergent validity. The discriminant validity was assessed using Fornell and Larcker (1981) by comparing the square root of each AVE in the diagonal with the correlation coefficients (off-diagonal) for each construct in the relevant rows and columns.

TABLE 1. Psychometric properties for first order constructs

\begin{tabular}{|c|c|c|c|c|c|c|}
\hline Constructs & Items summary & Loadings & $\mathbf{C R}$ & CA & rho_A & AVE \\
\hline & ical instability & 0.960 & 0.965 & 0.951 & 0.952 & 0.873 \\
\hline
\end{tabular}




\begin{tabular}{llllllll}
\hline & Legal procedural barrier & 0.968 & & & & \\
& Lack of express service & 0.899 & & & & \\
& Corruption & 0.908 & & & & \\
& & & & & & \\
Social & Different language & 0.952 & 0.955 & 0.936 & 0.941 & 0.842 \\
& Different social approaches & 0.949 & & & & \\
& Shortage of skilled labour & 0.943 & & & & \\
& Shortage of training facility & 0.820 & & & & \\
& & & & & & \\
Economic & Lack of finance & 0.853 & 0.907 & 0.862 & 0.865 & 0.709 \\
& Non-preferential custom duty & 0.819 & & & & \\
& Non-preferential tax & 0.908 & & & & \\
& Foreign exchange risk & 0.783 & & & & \\
\hline
\end{tabular}

The AVE's square root value are higher than their coefficients in the correlation matrix leading us to deduce that the results (see Table 4), the evaluation of the measurement model and the model itself are satisfactorily reliable and valid (convergent and discriminant).

TABLE 3. Fornell-Larcker Criteria

\begin{tabular}{llll}
\hline & Economic & Political & Socio-cultural \\
\hline Economic & $0.842^{*}$ & & \\
Political & 0.748 & $0.934^{*}$ & \\
Social & 0.723 & 0.724 & $0.918^{*}$ \\
\hline
\end{tabular}

Note: Square root of AVE on the diagonal*

\subsection{Assessment of the HR Model}

Using the empirical data, an HR model was validated using the social and politico-economic barriers (see Figure 2). The hypotheses show variation as follows (Political - 84\%, Social $82 \%$ and Economic - 81\%). The result in Table 4 shows significant path coefficients between the hypotheses (barriers) at po0.01. This should therefore be included in the 'best fit' approach to SMEs' internationalisation.

\subsection{Analysis of structural model and results of hypotheses testing}


This paper has shown the relationship between social, political and economic barriers and their sub-hypotheses in order to measure the model's validity (see Figure 3). There is a strong relationship between the major variables selected at $0.917,0.904$ and 0.897 respectively. The significance of the path coefficients is highlighted (1\%) lending credence to our hypotheses (see Table 4).

TABLE 4. Analysis of Structural Model Path Coefficients (Mean, STDEV, T-Values)

\begin{tabular}{cccccc}
\hline & $\begin{array}{c}\text { Original } \\
\text { Sample } \\
\text { coefficient }\end{array}$ & $\begin{array}{c}\text { Sample Mean } \\
\text { coefficient }\end{array}$ & $\begin{array}{c}\text { Standard } \\
\text { Deviation } \\
\text { (STDEV) }\end{array}$ & $\begin{array}{c}\text { P } \\
\text { Values }\end{array}$ & $\begin{array}{c}\text { T } \\
\text { Statistics }\end{array}$ \\
\hline $\begin{array}{c}\text { Overall } \\
\text { Barriers -> } \\
\text { Political }\end{array}$ & 0.917 & 0.917 & 0.014 & 0.000 & 63.957 \\
$\begin{array}{c}\text { Overall } \\
\text { Barriers -> }\end{array}$ & 0.904 & 0.903 & 0.016 & 0.000 & 55.925 \\
Social & & & & & \\
Overall & 0.897 & 0.898 & 0.019 & 0.000 & 46.697 \\
Barriers -> & & & & & \\
Economic & & & & & \\
\hline
\end{tabular}

TABLE 5. Results on Hypotheses

\begin{tabular}{llll}
\hline Hypotheses & $\begin{array}{l}\text { Path } \\
\text { coefficient }\end{array}$ & t-value & Conclusion \\
\hline $\begin{array}{l}\text { H1a: Political instability best fit with the political } \\
\text { barriers of SMEs' internationalisation and }\end{array}$ & 0.961 & 132.455 & Supported \\
management practices. & & 168.952 & Supported \\
$\begin{array}{l}\text { H1b: Legal procedural barriers best fit with the } \\
\text { political barriers of SMEs' internationalisation and } \\
\text { management practices. }\end{array}$ & 0.968 & & \\
$\begin{array}{l}\text { H1c: Lack of express service best fit with the } \\
\text { political barriers of SMEs' internationalisation and } \\
\text { management practices. }\end{array}$ & 0.899 & 38.238 & Supported \\
$\begin{array}{l}\text { H1d: Corruption best fit with the Political barriers } \\
\text { of SMEs' internationalisation and management } \\
\text { practices. }\end{array}$ & 0.908 & 50.348 & Supported \\
\end{tabular}


H2a: Different language best fit with the Social barriers of SMEs' internationalisation and management practices.

H2b: Different social approaches best fit with the social barriers of SMEs' internationalisation and management practices.

H2c: Shortage of skilled labour best fit with the social barriers of SMEs' internationalisation and management practices.

$\mathrm{H} 2 \mathrm{~d}$ : Shortage of training facility best fit with the social barriers of SMEs' internationalisation and management practices.

H3a: Lack of finance best fit with the economic barriers of SMEs' internationalisation and management practices.

$\mathrm{H} 3 \mathrm{~b}$ : Non-preferential customs duty best fit with the economic barriers of SMEs' internationalisation and management practices.

H3c: Non-preferential tax best fit with the economic barriers of SMEs' internationalisation and management practices.

H3d: Foreign exchange risk best fit with the economic barriers of SMEs' internationalisation and management practices.
$0.952 \quad 107.343 \quad$ Supported

0.949

124.299 Supported

$0.943 \quad 98.295 \quad$ Supported

$0.820 \quad 29.716 \quad$ Supported

$0.853 \quad 35.394 \quad$ Supported

$0.819 \quad 22.122 \quad$ Supported

$0.908 \quad 58.577 \quad$ Supported

$0.783 \quad 21.842 \quad$ Supported 
FIGURE 3. Main Loadings of the Model on internationalisation barriers for SMEs

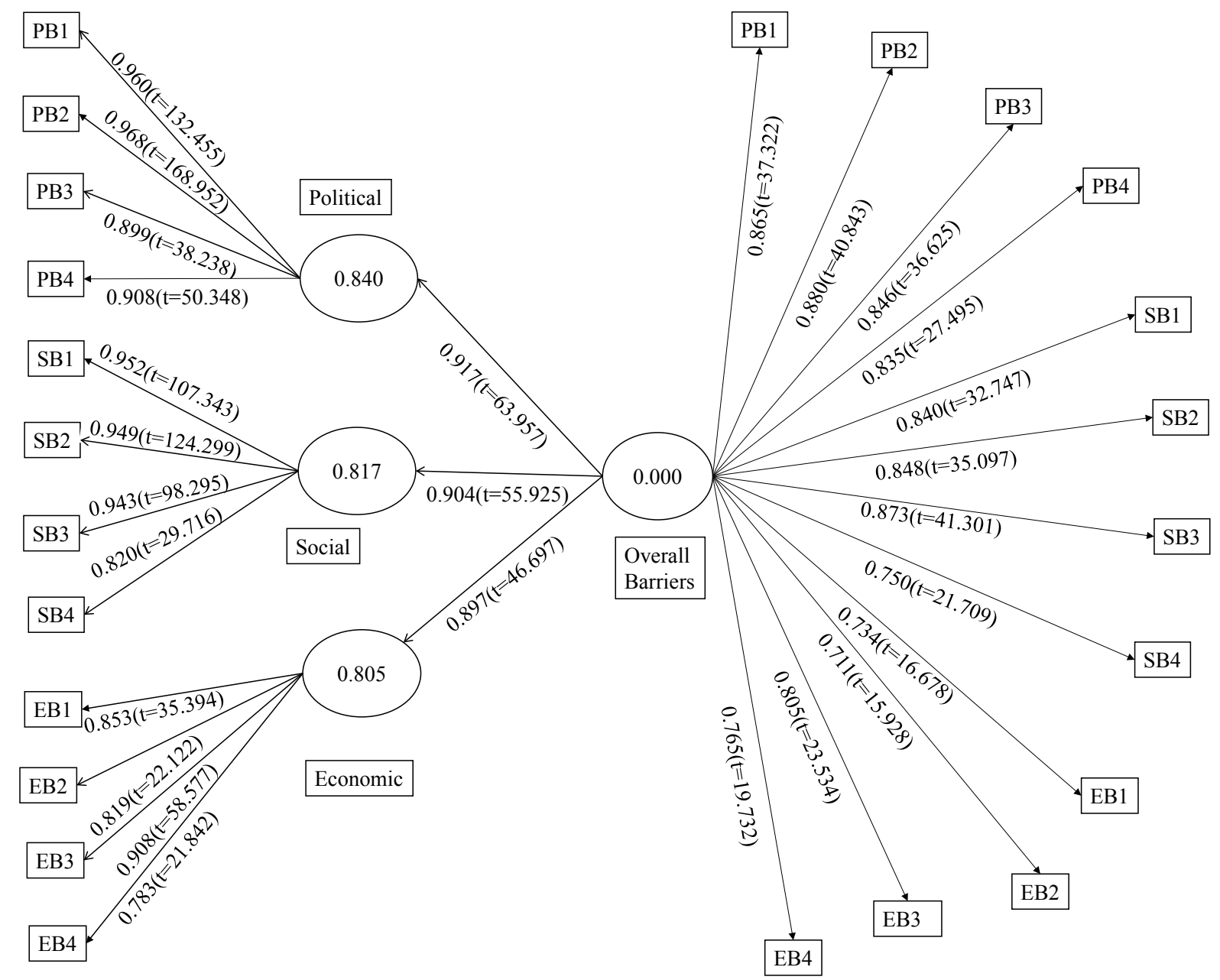

\subsection{Summary of results}

In order to identify how to use politico-economic and social barriers to study SMEs' internationalisation and management practices from a developing country, we used the 'best fit' approach. The literature provided the basis to identify three major hypotheses, which were validated into the study's HR model. We found it beneficial to explain the respective social and politico-economic barriers faced by Bangladeshi SMEs' internationalisation despite the globalisation claims (Ghauri et al., 2016) and the need to contribute theoretically (Paul, Parthasarathy \& Gupta, 2017). Our study has contributed in extending our knowledge of the significant SMEs' internationalisation barriers and management practices, some of which had 
been alluded to (Boxall \& Purcell, 2003) but not developed in the way we did here, using SMEs in a developing country context. This study has highlighted that people and other factors (e.g. social) are significant for SMEs internationalisation in a small developing country context compared to previous studies' emphasis on markets (Cowling, et al., 2015) and globalisation's pace (Ghauri et al., 2016).

It has effectively progressed the barriers from an 'inward'/'outward' mobility angle (Balboni, Bortoluzzi \& Grandinetti, 2013) to a people management model to facilitate such mobility of goods and services internationally. Given that all the dimensions reflect overall the social and politico-economic barriers as they have been constructed we have extended SteinerowskaStreb and Steiner's (ibid) work. Additionally, the extension supports the call to fit 'best fit' (Paauwe \& Boselie, 2003) within the political, social and economic frames as part of an overall theoretical umbrella to analyse the internationalisation activities of SMEs in developing countries. Therefore, the 'best fit' approach needs amending such that it also includes social aspects highlighting the cultural issues that Okpara and Kabongo (2010) noted earlier. 84 percent of overall variance was explained by politically- oriented barriers followed by 82 per cent for social and 81 per cent for economic barriers. On the basis of the results of this paper, it can be recommended that these hypotheses and their sub-dimensions are given due consideration in SME and HRM research.

When we set out to study whether there was a relationship between the latent variables (i.e. the hypotheses) we were pleased to discover through empirically-testing the data using SmartPLS 3 that an HR model could be validated especially when this had not been attempted from a Bangladeshi perspective. Our model explains the interaction between the variables/hypotheses and their complexity something that previous studies thought would be outpaced by the pace of globalisation (Ghauri et al., 2016). Having validated the empirical results of $\mathrm{H} 1, \mathrm{H} 2$ and $\mathrm{H} 3$, our study has shown how to highlight all the major internationalisation barriers, some of which 
were partly treated individually earlier by Wold (1985). SME internationalisation and the 'best fit' approach have not attempted what we did here. Therefore, this study has extended Pauuwe and Boselie (2003) and Becker and Huselid's (2006) work. The hypotheses in this paper highlight the major barriers needing people management support as propounded by Van Wanrooy et al. (2013), among others.

\subsection{DISCUSSION}

The benefits of this paper's results are argued as follows. Quite importantly, they show which areas SME entrepreneurs and workers need to focus on when they sell their goods and services in foreign environments. It is clear from the findings that politico-economic conditions can pose significant risks to SMEs' expansion internationally. Political barriers are slightly more significant compared to the economic and social counterparts. To add to Okpara and Kabongo (2010), we suggest that politics, economics and social aspects be studied alongside the subhypotheses (see H1a, b, c \& d; H2a, b, c \& d \& H3a, b, c \& d) for a more complex and richer understanding of SME internationalisation.

Our study used and extended 'best fit' approach by highlighting earlier missing aspects such as economic and social conditions that need to be incorporated if HR professionals are to manage people more effectively in the four districts that the Bangladeshi SMEs were located. We therefore propose that politico, socio-economic aspects be wrapped up as a composite mix of how to manage people in developing countries to complement the global perspective that Ghauri et al. (2016) and Liñán, Paul and Fayolle (2019) proposed earlier. Doing so is anticipated will generate additional resource capability and retaining the necessary skills to counteract the resources, training and development and corruption constraints faced by many SMEs (Chen, Liu \& Su, 2013). 
Given that social and economic barriers pose less risks to internationalisation, SMEs need to focus greater attention to the political environmental barriers as opposed to previous postulation (Kaufman's (2015) in which economic, market aspects were over-rated. The need for HR to step up a mark becomes more resounding as a practical argument that contributes to the theoretical debates suggested by Paul, Parthasarathy and Gupta (2017). The model for doing so is presented (see Figure 2) and is geared towards developing such a theorisation/approach of managing people in international SME contexts. People in developing countries need adequate assistance if their SMEs are to thrive in international geographic dispensations.

\subsection{Paper's Contributions}

This paper contributes on three levels, theoretically, methodologically and practically. Theoretically, we developed an HR model, which highlights 8 variables that can be problematic when SMEs apply people management processes. An examination of the SME and internationalisation literatures in the missing aspects of barriers of SMEs' internationalisation produced results demonstrating a slightly significant weighting of political issues over socioeconomic barriers. Previous studies such as Ardito et al., (2018) and Portilla et al., (2017) missed this earlier. We have extended Jaworski's (2011) two-phased inward/outward model by providing further insights into three key barriers (political, economic and social) that impact on the survival of SMEs whereas Paul and Anantharaman (2003) focused on some people management practices globally (Liñán, Paul \& Fayolle, 2019). Due regard should also be given to other aspects as Bangladeshi SMEs are internationalising goods and services as an addition to Paul, Parthasarathy and Gupta's (2017) theorisation.

Methodologically, the possibility to enhance SMEs' survival in a developing country can be assisted not only via traditional training and development (Marchington \& Grugulis, 2000) or technological innovation (Booltink \& Saka-Helmhout, 2018) but by developing a model 
highlighting what the key barriers to their survivability and international relationships are (see Table 5). Therefore, a methodological insight into the testing of various key constructs of internationalisation within an integrative process approach has been missing and therefore is a contribution rather than identifying the wheels' (Dreher \& Gassebner 2013; Maharjan \& Sekiguchi, 2016) needing to be 'greased' as before.

Practically our tested and validated results can help policy makers to be able to identify the barriers to required behaviours to sustain SMEs' operational success internationally. The study has therefore extended our knowledge of the previously limited set of practical barriers that SMEs and international entrepreneurs face. Previous studies were limited to economic and financial constraints (Naldi et al., 2007) without highlighting how innovation and skills' development constraints (Krishnan \& Scullion, 2017; Booltink \& Helmhout, 2018) are captured in a model that could practically help resolve SMEs' internationalisation barriers. Focusing on the politico-economic and social aspects of internationalisation can help in this direction. To this end, necessary programmes to develop the three aspects are crucial to mitigate against the barriers in the HR model (e.g. skilled labour or human capital shortage Dar \& Mishra, 2019; Mustafa \& Yaakub, 2018).

\subsection{CONCLUSION}

Insofar as this paper's main objective of using the 'best fit' approach to study the major barriers to SMEs' internationalisation is concerned, we have achieved this as follows. We identified a developing country - Bangladesh, which has not benefited from people management of internationalisation before. The limitations of the 'best fit' approach were identified by using the data and theorising on the three major hypotheses. An HR model was validated by using SmartPLS 3 to highlight that political, economic and social aspects related to people and other 
factors need more urgent attention within SMEs than what Boxall and Purcell (2003), Becker and Huselid (2006) and Kaufman propounded in earlier research.

The support for each of the three hypotheses (Table 5) is another significant milestone in the sense that previous studies as cited have emphasised on either economic or cultural aspects at the neglect of the barriers we highlighted and validated in a model. Future studies in people management should focus on these hypothesised barriers and include them in their model and methodological discussions and emerging 'globalisation' frames (Buckley et al., 2016). This suggests that social, political and economic barriers remain a missing research conundrum worthy of further investigation especially with the use of smarter versions of the PLS software or other latest forms.

Future research could also look into migration and skills movements as part of global trends (Liñán, Paul \& Fayolle, 2019) to ascertain whether these might pose new barriers to SMEs and their internationalisation efforts. There also appears to be a new research opening for scholars and practitioners who may wish to look into some of the issues highlighted here by comparing European, American, African and Asian perspectives on internationalisation activities.

\subsection{Study's Limitations}

This study's constraints are as follows. Initially, our model is validated on the results from four districts in Bangladesh. We are not claiming that the model can be applied anywhere, anytime as previous studies have done, given their scale (Buckley \& Ghauri, 2016). We collected date within a single year's timeframe but other studies could adopt a longer span to see whether variations could become more complex and/or nuanced over time. Whether theoretical developments can be accrued by having a longer-span study using additional variables and measurement tools is yet to be seen from those conducted in the seminal works of Buckley and Ghauri (2016). 


\section{REFERENCES}

Agwu, M. O. \& Emeti, C. I. (2014). Issues, challenges and prospects of small and medium scale enterprises (SMEs) in Port-Harcourt city. European Journal of Sustainable Development, 3(1), 101-114.

Akter, M. S., Rajasekera, J. \& Rahman, M. M. (2010). Serving the poor by marketing information: developing a sustainable village phone model in Bangladesh. International Journal of Economics and Business Research, 2: 3, 288-309.

Alon, I. \& Rottig, D. (2013). Entrepreneurship in emerging markets: New insights and directions for future research. Thunderbird International Business Review, 55: 5, 487-492.

Armstrong, M. (2015). Armstrong's Handbook of Performance Management: An evidencebased guided to delivering high performance. London: Kogan Page.

Balboni, B., Bortoluzzi, G., \& Grandinetti, R. (2013). On the relationship between size, capabilities and internationalisation: an explorative analysis of Italian subcontracting SMEs. International Journal of Globalisation and Small Business, 5(1-2), 114-132.

Becker, B. E. \& Huselid, M. A. (2006). Strategic human resources management: where do we go from here? Journal of Management, 32(6), 898-925.

Beine, M., Docquier, F., \& Rapoport, H. (2008). Brain drain and human capital formation in developing countries: winners and losers. The Economic Journal, 118(528), 631-652.

Benito-Hernández, S., López-Cózar-Navarro, C. \& Priede-Bergamini, T. (2015). Examining the relationship between firm size and external advice on legal matters and human resources by family businesses. Journal of Business Economics and Management, 16: 3, 483-509. 
Balboni, B., Bortoluzzi, G., \& Grandinetti, R. (2013). On the relationship between size, capabilities and internationalisation: an explorative analysis of Italian subcontracting SMEs. International Journal of Globalisation and Small Business, 5(1-2), 114-132.

Booltink, L. W., \& Saka-Helmhout, A. (2018). The effects of R\&D intensity and internationalization on the performance of non-high-tech SMEs. International Small Business Journal, 36(1), 81-103.

Boso, N., Oghazi, P., Cadogan, J. W. \& Story, V. M. (2016). Entrepreneurial and MarketOriented Activities, Financial Capital, Environment Turbulence, and Export Performance in an Emerging Economy. Journal of Small Business Strategy, 26: 1, 1-24.

Boxall, P. \& Purcell, J. (2003). Strategy and Human Resource Management. Hampshire: Palgrave-Macmillan.

Brereton, R. G. \& Lloyd, G. R. (2014). Partial least squares discriminant analysis: taking the magic away. Journal of Chemometrics, 28(4), 213-225.

Brouthers, K. D., Nakos, G., \& Dimitratos, P. (2015). SME entrepreneurial orientation, international performance, and the moderating role of strategic alliances. Entrepreneurship Theory and Practice, 39(5), 1161-1187.

Buckley, P. J. \& Ghauri, P. N. (2016 eds.) (1999). The Global Challenge for Multinational Enterprises: Managing Increasing Interdependence. Pergamon.

Cavusgil, S. T., \& Knight, G. (2015). The born global firm: An entrepreneurial and capabilities perspective on early and rapid internationalization. Journal of International Business Studies, 46(1), 3-16.

Chetty, S. \& Holm, D. B. (2000). Internationalisation of small to medium-sized manufacturing firms: a network approach. International Business Review, 9: 1, 77-93. 
Chen, Y., Liu, M., \& Su, J. (2013). Greasing the wheels of bank lending: Evidence from private firms in China. Journal of Banking \& Finance, 37(7), 2533-2545.

Cowling, M., Liu, W., Ledger, A. \& Zhang, N. (2015). What really happens to small and medium-sized enterprises in a global economic recession? UK evidence on sales and job dynamics. International Small Business Journal, 33: 5, 488 - 513.

Dar, I. A., \& Mishra, M. (2019). Human Capital and SMEs Internationalization: Development and Validation of a Measurement Scale. Global Business Review.

Domeher, D., Musah, G., \& Hassan, N. (2017). Inter-sectoral differences in the SME financing gap: evidence from selected sectors in Ghana. Journal of African Business, 18(2), 194220.

Edmondson, A. C. \& Harvey, J. F. (2017). Cross-boundary teaming for innovation: Integrating research on teams and knowledge in organizations. Human Resource Management Review. March.

O'Farrell, P. N., Zheng, J., \& Wood, P. A. (1996). Internationalization of business services: an interregional analysis. Regional Studies, 30(2), 101-118.

Fletcher, M., \& Prashantham, S. (2011). Knowledge assimilation processes of rapidly internationalising firms: longitudinal case studies of Scottish SMEs. Journal of Small Business and Enterprise Development, 18: 3, 475-501.

Fornell, C. \& Larcker, D. F. (1981). Structural equation models with unobservable variables and measurement error: Algebra and statistics. Journal of Marketing Research, 382-388.

Ghosh, A. R., Ostry, J. D. \& Chamon, M. (2016). Two targets, two instruments: monetary and exchange rate policies in emerging market economies. Journal of International Money and Finance, 60, 172-196. 
Gunaratne, S. A. (2009). Globalization: A Non-Western Perspective: The Bias of Social Science/Communication Oligopoly. Communication, Culture \& Critique, 2: 1, 60-82.

Harrison, J. S., Boivie, S., Sharp, N. Y., \& Gentry, R. J. (2018). Saving face: How exit in response to negative press and star analyst downgrades reflects reputation maintenance by directors. Academy of Management Journal, 61(3), 1131-1157.

Hong, J. \& Lu, J. (2016). Assessing the effectiveness of business incubators in fostering SMEs: evidence from China. International Journal of Entrepreneurship and Innovation Management, 20: 1-2, 45-60.

Hulland, J. (1999). Use of partial least squares (PLS) in strategic management research: a review of four recent studies. Strategic Management Journal, 20: 2, 195-204.

Jarvis, C. B., MacKenzie, S. B. \& Podsakoff, P. M. (2003). A critical review of construct indicators and measurement model misspecification in marketing and consumer research. Journal of Consumer Research, 30: 2, 199-218.

Jaworski, B., Kohli, A. K. \& Sahay, A. (2011). Market-driven versus driving markets. Journal of the Academy of Marketing Science, 28: 1, 45-54.

Jones, E. S., Mullen, R. \& Hardy, L. (2019). Measurement and validation of a three factor hierarchical model of competitive anxiety. Psychology of Sport and Exercise, 43, 34-44.

Kamakura, W. A., Ramón-Jerónimo, M. A., \& Gravel, J. D. V. (2012). A dynamic perspective to the internationalization of small-medium enterprises. Journal of the Academy of Marketing Science, 40(2), 236-251.

Kaufman, B. E. (2015). Market competition, HRM and firm performance: The conventional paradigm critiqued and reformulated. Human Resource Management Review, 25: 1, 107125. 
Kline, T. J., Sulsky, L. M. \& Rever-Moriyama, S. D. (2000). Common method variance and specification errors: A practical approach to detection. The Journal of Psychology, 134: 4, 401-421.

Li, X., Segarra Roca, P., \& Papaoikonomou, E. (2011). SMEs' responses to the financial and economic crisis and policy implications: an analysis of agricultural and furniture sectors in Catalonia, Spain. Policy Studies, 32(4), 397-412.

Liesch, P. W., Welch, L. S., \& Buckley, P. J. (2014). Risk and uncertainty in internationalisation and international entrepreneurship studies. In The Multinational Enterprise and the Emergence of the Global Factory. London: Palgrave Macmillan, 5277.

Liñán, F., Paul, J., \& Fayolle, A. (2019). SMEs and entrepreneurship in the era of globalization: advances and theoretical approaches. Small Business Economics, 1-9.

Lindner, T., Muellner, J., \& Puck, J. (2016). Cost of capital in an international context: institutional distance, quality, and dynamics. Journal of International Management, 22(3), 234-248.

Madrid-Guijarro, A., García-Pérez-de-Lema, D., \& Van Auken, H. (2013). An investigation of Spanish SME innovation during different economic conditions. Journal of Small Business Management, 51: 4, 578-601.

Marchington, M. \& Grugulis, I. (2000). 'Best practice' human resource management: Perfect opportunity or dangerous illusion?' International Journal of Human Resource Management, 11, 1104-1124.

Masurel, E., \& Van Montfort, K. (2006). Life Cycle Characteristics of Small Professional Service Firms. Journal of Small Business Management, 44: 3, 461-473. 
Mendoza, R. U., Lim, R. A., \& Lopez, A. O. (2015). Grease or sand in the wheels of commerce? Firm level evidence on corruption and SMEs. Journal of International Development, 27(4), 415-439.

Mendy, J. (2017). 'Key HRM Challenges and Benefits: The Contributions of the HR Scaffolding'. In J. Mendy (eds.) Teaching Human Resources and Organizational Behavior at the College Level. Pennsylvania: IGI Global, 1 - 57.

Mendy, J. \& Rahman, M. (2018). 'Evaluating People-related Resilience and Non-Resilience Barriers of SMEs' Internationalisation: A developing country perspective', International Journal of Organisational Analysis, 27(2), 225 - 240

Mendy, J. \& Rahman, M. (2018). ‘Application of HRM's Universal Model: an examination of People vs Institutions as Barriers of Internationalization for SMEs in a Small Developing Country', Thunderbird International Business Review, 61(2), 363 - 374.

Mustafa, H. K., \& Yaakub, S. (2018). Innovation and Technology Adoption Challenges: Impact on SMEs' Company Performance, International Journal of Accounting, 3(15), 57 65.

Mwaura, M. F., \& Nyaboga, A. B. (2009). International financial accounting standards and the continent of Africa. International Business \& Economics Research Journal (IBER), 8: 3.

Naldi, L., Nordqvist, M., Sjöberg, K. \& Wiklund, J. (2007). Entrepreneurial orientation, risk taking, and performance in family firms. Family Business Review, 20(1), 33-47.

Naumann, J., Richter, T., Christmann, U., \& Groeben, N. (2008). Working memory capacity and reading skill moderate the effectiveness of strategy training in learning from hypertext. Learning and Individual Differences, 18(2), 197-213.

Newman, A., Borgia, D. \& Deng, Z. (2013). How do SMEs with single and multiple owners finance their operations differently? Empirical evidence from China', Thunderbird International Business Review, 55: 5, 531-544. 
Okpara, J. \& Kabongo, J. (2011). Export barriers and internationalization: Evidence from SMEs in emergent African economy. International Journal of Business and Globalization, 5: 2, 169-187.

Paauwe, J. \& Boselie, P. (2005). HRM and performance: what next? Human Resource Management Journal, 15(4), 68-83.

Pangarkar, N. (2008). Internationalization and performance of small-and medium-sized enterprises. Journal of World Business, 43: 4, 475-485.

Park, B., \& Ghauri, P. N. (2011). Key factors affecting acquisition of technological capabilities from foreign acquiring firms by small and medium sized local firms. Journal of World Business, 46: 1, 116-125.

Paul, J., Parthasarathy, S., \& Gupta, P. (2017). Exporting challenges of SMEs: A review and future research agenda. Journal of world business, 52(3), 327-342.

Paul, J., \& Shrivatava, A. (2016). Do young managers in a developing country have stronger entrepreneurial intentions? Theory and debate. International Business Review, 25(6), 1197-1210.

Paul, A. K. \& Anantharaman, R. N. (2003). Impact of people management practices on organizational performance. International Journal of Human Resource Management, 14, $1246-1266$.

Podsakoff, P. M. \& Organ, D. W. (1986). Self-reports in organizational research: Problems and prospects. Journal of Management, 12: 4, 531-544.

Rahman, M., Uddin, M. \& Lodorfos, G. (2017). Barriers to enter in foreign markets: evidence from SMEs in emerging market. International Marketing Review, 34: 1, 68-86.

Ringle, C. M., Wendy, S. \& Becker, J. M. (2015). "SmartPLS 3." Boenningstedt: SmartPLS. 
Ruzzier, M., AntonciC, B., Hisrich, R. D., \& Konecnik, M. (2007). Human capital and SME internationalization: A structural equation modeling study. Canadian Journal of Administrative Sciences/Revue Canadienne des Sciences de l'Administration, 24(1), 1529.

Saridakis, G., Yanqing, L. \& Cooper, C. L. (2017). Exploring the relationship between HRM and firm performance: A meta-analysis of longitudinal studies. Human Resource Management Review, 27: 1, 87-96.

Steinerowska-Streb, I. \& Steiner, A. (2014). An analysis of external finance availability on SMEs' decision making: A case study of the emerging market of Poland. Thunderbird International Business Review, 56: 4, 373-386.

Stone, D. L., Deadrick, D. L., Kimberly, M. L. \& Lukaszewski, R. J. (2015). The influence of technology on the future of human resource management. Human Resource Management Review, 25: 2, 216-231.

Top, M., Akdere, M. \& Turcan, M. (2015). Examining transformational leadership, job satisfaction, organizational commitment and organizational trust in Turkish hospitals: public servants versus private sector employees. International Journal of Human Resource Management, 26(9), 1259-1282.

Ulrich, D. \& Dulebohn, J. H. (2015). Are we there yet? What's next for HR? Human Resource Management Review, 25, 188-204.

Van Wanrooy, B., Bewley, H., Bryson, A., Forth, J., Freeth, S., Stokes, L. \& Wood, S. (2013). Employment Relations in the Shadow of Recession: Findings from the 2011 Workplace Employment Relations Study. London: Palgrave.

Von Bonsdorff, M. E., Janhonen, M., Zhou, Z. E. \& Vanhalad, S. (2015). Team autonomy, organizational commitment and company performance - a study in the retail trade. International Journal of Human Resource Management, 26: 8, 1098-1109. 
Wetzels, M., Schroder, G. O. \& Oppen, V. C. (2009). Using PLS path modeling for assessing hierarchical construct models: Guidelines and empirical illustration. MIS Quarterly, 33: 1, $177-195$.

Wickramasekera, R. \& Oczkowski, E. (2006). Stage models re-visited: a measure of the stage of internationalisation of a firm. Management International Review, 46: 1, 39-55.

Williams, N. L., Ridgman, T., Shi, Y. \& Ferdinand, N. (2014). Internationalization as interaction: A process perspective on internationalization from a small developing country. Thunderbird International Business Review, 56: 2, 127-144.

Zoogah, D. \& Mburu, H. K. (2015). Are Firms in Developing Countries in Spider Webs or Iron Cages? Geographic Traps and Firm Performance. Thunderbird International Business Review, 57: 6, 481-503. 